\title{
Teologiczna ocena przymierza Judy Machabeusza z Rzymem. Intertekstualna analiza 1 Mch 8,17-20
}

\section{Wstęp}

Tematyka poniższego artykułu wpisuje się w postulat głębszych badań nad biblijną interpretacją postępowania Żydów w świetle zapisów prawa Mojżeszowego w końcowym etapie historii Izraela, przed nastaniem czasów Nowego Testamentu. Dziś powszechnie wiadomo, że tradycja deuteronomistyczna Starego Testamentu w taki właśnie sposób oceniała całościową historię narodu wybranego, poczynania jego władców na północy i południu oraz zachowanie się całego ludu przymierza. Najbardziej bodaj przekonującym tego świadkiem jest tekst $2 \mathrm{Krl}$ 17,1-18 relacjonujący zdobycie Samarii i upadek królestwa północnego w roku 622. Hagiograf teologicznie ocenił sekwencję zdarzeń kończących polityczną egzystencję Izraela, a królestwo południowe powoli dogorywało w konwulsjach własnych niewierności. Natomiast mniej rozpatrywany jest jak dotąd okres drugiej świątyni w jej finalnym stadium, jakim jest II wiek przed Chr., czego świadkami są w szczególności obie Księgi Machabejskie, badane rzadziej, zwłaszcza na tle rozwiniętej egzegezy protokanonicznych ksiąg Biblii hebrajskiej. Dlatego każdy z naukowców zgodzi się, że trzeba im poświęcić więcej uwagi w dokonywanych analizach materiału biblijnego. Księgi Machabejskie należą do części historycznej Pisma Świętego, w której szkoła deuteronomi-

1 Ks. Janusz Nawrot, prof. dr hab. — ur. w 1960 roku w Międzychodzie, woj. wielkopolskie; kapłan archidiecezji poznańskiej od 1985 roku; wykładowca WT UAM w Poznaniu; pracownik Zakładu Teologii Historycznej; specjalizuje się w egzegezie i teologii Starego Testamentu; e-mail: jannaw@amu.edu.pl. ORCID: 0000-0002-2498-5081. 
styczna miała najwięcej do powiedzenia ze wszystkich trzech wielkich nurtów słowa Bożego Starego Testamentu. Oceniając postępowanie władców Izraela i Judy w świetle wierności Bożym nakazom, dała impuls do przedłużenia tego sposobu interpretacji historii Izraela także w wiekach późniejszych.

Obecny artykuł stanowi ostatnią część tryptyku egzegetycznego, rozpoczętego analizą tekstów prawniczych zakazujących wchodzenia w przymierza ze społecznościami pogańskimi oraz egzegezą kilku sztandarowych fragmentów podlegających tym zakazom ${ }^{2}$. W części drugiej zostały przeegzaminowane przypadki zawierania przymierzy lub paktów między bohaterami biblijnymi a władcami narodów ościennych. Układy te nie podpadały pod zakazy Mojżeszowe, jeśli podstawą oraz celem ich zawierania były wyłącznie działania natury politycznej lub handlowej, nie zaś jakiekolwiek kwestie związane z możliwością naruszenia wiary w jedynego Boga Izraela. Takie niebezpieczeństwo z racji zawarcia układów tego rodzaju nie wchodziło w grę jedynie w przypadku Abrahama z Abimelekiem (Rdz 21,27.32) oraz Salomona z Chiramem (1 Krl 5,26). Natomiast zagrożenie dla wiary narodu pojawiło się w układach między Asą a Ben-Hadadem I (1 Krl 15,19; 2 Krn 16,3), Achaba z Ben-Hadadem II (1 Krl 21,1-34), Achaza z Tiglat-pileserem III (2 Krl 16,7-9; 2 Krn 28,16-21), królestwem judzkim a Egiptem (Iz 30,1-5) czy wreszcie w pakcie między Sedecjaszem a Nabuchodonozorem II (Ez 17,13). We wszystkich tych wypadkach polityczne zabiegi między władcami Izraela i Judy a monarchami pogańskimi stanowiły w rzeczywistości odrzucenie przymierza z Bogiem Izraela ${ }^{3}$.

$\mathrm{W}$ obecnej, trzeciej części tryptyku zostanie omówiony przypadek, kiedy według relacji biblijnej Juda Machabeusz, posyłając swych przedstawicieli do Rzymu ok. roku $161^{4}$ przed Chr., występuje jako przedstawiciel swego ludu,

2 Por. J. Nawrot, Izrael wobec zakazu sprzymierzania się z poganami $w$ wybranych tekstach Septuaginty: część I, PST 34 (2019), s. 7-28.

${ }^{3}$ Por. tenże, Alliances between Israel and Other Nations in Light of the Pentateuch's Prohibitions in the Greek Bible, PST 35 (2020), s. 29-48.

${ }^{4}$ Różne są oceny historyczności układu między Judą Machabeuszem i Żydami a republiką. Według M. Sterna nie ma powodu, by wątpić w autentyczność traktatu, jeśli łączyć go zwłaszcza z buntem Timarchosa we wschodniej części imperium Seleucydów. Możliwe, że bunt ów wywarł wpływ na decyzję rzymskiego senatu, by zawrzeć traktat z Judą, por. M. Stern, The Treaty between Judaea and Rome in 161 BCE, „Zion” 51 (1986), s. 3-28. Z drugiej jednak strony dokument układu Judy z Rzymem nie jest wspomniany w źródłach nieżydowskich. Według L. Zollschana wysoce wątpliwe jest, aby mógł on zostać zawarty w 161 roku przed Chr., por. L. Zollschan, The Senate and the Jewish Embassy of 161 BCE [w:] The Path of Peace: Studies in Honor of Israel Friedman Ben-Shalom, ed. by D. Gera et al., Beersheva 2005, s. 1-37. Poza tym, jak już argumentował L. Mendelssohn, żydowskim ambasadorom udało się jedynie uzyskać status politycznej amicitia od rzymskiego senatu, ponieważ Rzymianie nie chcieli dawać statusu foedus państwom, które nie były wolne. Status ten został osiągnięty przez Żydów dopiero za czasów Szymona Machabeusza. Dalsza dyskusja, por. M. Rocca, The Late Roman Republic and Hasmonean Judaea, „Athenaeum” 102 (2014) 1, s. 55. 
podczas gdy nie nosił żadnego oficjalnego tytułu, by reprezentować swój naród, i z tej racji nie posiadał żadnej legitymizacji de iure. Stąd jedynym fundamentem zainteresowania republiki rzymskiej mogłoby być działanie Judy de facto, na podstawie odniesionych przez niego zwycięstw nad wielkimi wodzami monarchii seleuckiej ${ }^{5}$. Niektórzy badacze uważają zwrot Judy ku Rzymowi za historycznie do zaakceptowania zwłaszcza po możliwych, lecz nieudanych negocjacjach między Judą a Nikanorem $(7,29)$. Otóż podczas spotkania dowódcy wojsk imperialnych $\mathrm{z}$ wodzem powstania mogło dojść do umowy przejęcia stanowiska arcykapłańskiego przez Judę z usunięciem Alkimosa, co załagodziłoby ostrość wystąpień machabejskich przeciw imperium i wygasiłoby stopniowo powstanie. Nie może w tym wypadku dziwić storpedowanie ewentualnych postanowień między oboma dowódcami przez Alkimosa na dworze królewskim i jego dalsze trwanie na urzędzie w Judei. Uniemożliwiło to z kolei Judzie przejęcie całej władzy nad ludem, zwłaszcza wobec części społeczeństwa, która była zainteresowana współpracą z Seleucydami, opowiadając się za Alkimosem na urzędzie arcykapłana. W takim razie zwrot Judy ku Rzymowi oznaczałby osłabienie władzy nikczemnego arcykapłana opartej na królu seleuckim i jego armii. Wobec gwarancji rzymskich Juda mógłby stać się arcykapłanem niezależnie od Seleucydów, za to z szerokim poparciem swych zwolenników i ogólnie patriotycznie nastawionej rzeszy rodaków ${ }^{6}$. W tym przypadku Juda mocno rozwinął swój polityczny instynkt, a szukając wsparcia w Rzymie, dał republice jeszcze jeden sposób ingerencji w wewnętrzne sprawy imperium seleuckiego ${ }^{7}$. Świadomość niewielkiego znaczenia Judei w mocarstwowych planach republiki mogła stać się podstawą do specyficznego, bardzo narzędziowego traktowania posłów z tego regionu przez senat. Dlatego otwarte pozostaje pytanie, czy przywódca powstania wierzył w szczerość Rzymu, czy świadomie dał się wykorzystać, będąc tylko pionkiem w wielkiej polityce bliskowschodniej tamtych czasów. Mógł przecież wierzyć, że z wielkiego stołu politycznej uczty Rzymu jakieś okruchy spadną także dla niego ${ }^{8}$.

Sposobem badania materiału biblijnego stanie się analiza intertekstualna przedstawiona szkicowo w jednym z poprzednich artykułów ${ }^{9}$, dlatego obecnie

${ }^{5}$ Por. J. Goldstein, I Maccabees: A New Translation, with Introduction and Commentary, AB 41, Garden City 1976, s. 357.

${ }^{6}$ Por. C. Seeman, Rome and Judea in Transition: Hasmonean Relations with the Roman Republic and the Evolution of the High Priesthood, New York 2013, s. 6.

${ }^{7}$ Por. B. Bar-Kochva, Judas Maccabaeus: The Jewish Struggle Against the Seleucids, Cambridge 2002, s. 86 .

${ }^{8}$ Ostatecznie inni sprzymierzeńcy republiki i jej klientela polityczna potrafili zawsze coś ugrać dla siebie, por. D. Gera, Judaea and Mediterranean Politics: 219 to 161 B.C.E., LeidenNew York 1998, s. 254.

${ }^{9}$ Por. J. Nawrot, Aluzje literackie $w$ teologicznej ocenie działań arcykapłana Szymona w 1 Mch 14,5, BibAn 11 (2021) 1, s. 5-23. 
nie będą już powielane ogólne jej zasady. W tym konkretnym wypadku zostanie zastosowana metoda łączenia słownictwa obecnego w wybranych wersetach Pierwszej Księgi Machabejskiej z terminologią tekstów wcześniejszych ksiąg Biblii greckiej, by ukazać zbieżność myśli teologicznej przytaczanych wersetów. Zastosowanie celowych aluzji pozwala uwidocznić właściwy zamiar literacki autora natchnionego, ponieważ właśnie one stają się najbardziej widocznym jego zabiegiem literackim w Pierwszej Księdze Machabejskiej. Postanowienie, jakie wyszło od wodza powstania machabejskiego zamieścił hagiograf dość lakonicznie w tekście 1 Mch 8,17-20. Każdy z wersetów ma swoją wymowę i znaczenie teologiczne. Warto je zatem rozpatrzyć kolejno po sobie następujące.

\section{Wybór posłów przez Judę Machabeusza}

Na początku teologicznego omówienia tekstu biblijnego należy zwrócić uwagę na to, że końcówka prezentowanego wersetu tematycznie pasuje bardziej do punktu omawiającego cel główny zawieranego paktu. Niemniej wyraźny związek słowotwórczy między czasownikami zamieszczonymi $\mathrm{w}$ wersecie $\mathrm{i}$ aluzja do cytatów starotestamentowych każe pozostawić całość tekstu w jednym miejscu.

\section{w. 17: Wybrat Juda Eupolemosa, syna Joannesa, syna Akkosa oraz Jazona, syna Eleazara $i$ wystat ich do Rzymu, by ustanowić przyjaźn i przymierze.}

Inicjatywa zawarcia układów z republiką rzymską wyszła od Judy i powstańców. Jest to o tyle dziwne, że — jak podaje Józef Flawiusz — wyłącznie arcykapłan mógł reprezentować swój naród na zewnątrz i podejmować decyzje o charakterze politycznym ${ }^{10}$. Nie jest łatwo rozwiązać historycznie sprawy Alkimosa

${ }^{10}$ Por. Ant. 11,4.8.111 oraz CAp 2,21.185; 22.188. Skoro jednak według Pierwszej Księgi Machabejskiej arcykapłanem był wówczas Alkimos, Flawiusz dokonał prawdopodobnie przeniesienia jego śmierci zaraz po zwycięstwie Judy nad Nikanorem, ignorując de facto wzmiankę o ostatnich dniach życia bezbożnego arcykapłana w 1 Mch 9,54-57. Mógł wówczas historyk żydowski założyć, że po śmierci Alkimosa właśnie Judę obwołano arcykapłanem (Ant. 12,10.6.414.419). Zapis ten doskonale wypełniałby powstałą lukę prawną, dając oficjalny tytuł Judzie do przeprowadzenia swej inicjatywy. Jeśli Flawiusz zawarł informację historyczną, wówczas pakt z republiką musiałby rzeczywiście nastać dopiero po śmierci lub usunięciu Alkimosa, zatem później, niż materiał księgi wskazuje, przestawiając kolejność śmierci obu bohaterów. Znienawidzony arcykapłan umarł według relacji hagiografa bowiem już po zabiciu Judy w bitwie pod Elasa $(9,56)$, por. J. Goldstein, I Maccabees..., s. 358. 
ani stwierdzić, czy Juda rzeczywiście posiadł tytuł arcykapłana. Pewność tę podważają odpisy oficjalnych listów danych posłom żydowskim, które nie wzmiankują Judy. Poza tym z pewnością można przypuszczać, że Demetriusz I nigdy nie zgodziłby się na nadanie oficjalnego tytułu arcykapłana wrogowi imperium. $\mathrm{Z}$ tego powodu można się domyślać także jakichś inicjatyw innych środowisk żydowskich, nieprzychylnych Alkimosowi zwłaszcza po jego zdradzie i zamordowaniu przedstawicieli tych kręgów społeczeństwa, które ewentualnie byłyby otwarte na kompromis z urzędnikami imperialnymi (7,12-18).

Tymczasem według relacji hagiografa sytuacja, jaka wykształciła się w wyniku działań Demetriusza I i jego wodzów ${ }^{11}$, zmusiła powstańców do podjęcia decyzji o zawarciu paktu $\mathrm{z}$ jedynym państwem mogącym pozytywnie odwrócić trudną sytuację militarną powstania. Czytając passus 8,1-16, odnosi się wrażenie, że podane zasady obowiązujące $\mathrm{w}$ republice stanowią całokształt wiedzy o Rzymianach na Bliskim Wschodzie. Warto jednak zwrócić uwagę na to, że wiadomości te dotyczą jedynie polityczno-społecznej sfery funkcjonowania. Zupełnie brakuje odniesienia do religijności rzymskiej, systemu wiary, sprawowanego kultu itd. Prawdopodobnie celowo hagiograf pominął wszelkie kwestie związane z religią, by zaznaczyć, że ta sfera życia republiki nie interesowała powstańców, skupionych wyłącznie na spodziewanych korzyściach militarno-politycznych wynikających z zawiązania paktu. Tym samym wskazał priorytety, które zawładnęły sercami przywódców powstania machabejskiego. Nie troszczyli się już oni wówczas o faktyczną zgodność z nakazami prawa Mojżeszowego, lecz na pierwszy plan wysuwali cele strategiczne ograniczające się do konkretnych efektów zawieranej umowy.

Autor oznajmia więc decyzję Judy i innych przywódców, by wysłać (apesteilen) dwóch godnych zaufania przedstawicieli, których obdarzył wszelkimi stosownymi pełnomocnictwami w celu ustanowienia (stēsai) traktatu. Spośród tekstów Biblii greckiej zawierających tę dwuczłonową sekwencję czasowników w tej samej kolejności ${ }^{12}$ na uwagę zasługuje zwłaszcza Jr 43,21 (LXX). Passus Jr 43,21-23 opowiada o nikczemnym postępowaniu króla Jojakima, który posłał (apesteilen) jednego ze swych sług, by przyniósł zwój proroka w celu odczytania go w obecności wszystkich jego doradców stojących (hestēkotōn) przy królu. Otóż podczas odczytywania słów proroctwa wysoce niepomyślnego dla kraju

${ }^{11}$ Rozdział 7 księgi wspomina o nowym etapie walk między monarchią seleucką a powstańcami za panowania Demetriusza I. Chodzi głównie o działania Bakchidesa i Nikanora, wodzów wojsk imperium, które permanentnie trapiły Machabeuszów i ich zwolenników.

12 Ta sama kolejność obu terminów występuje jeszcze w $1 \mathrm{Sm} \mathrm{19,20;} 2 \mathrm{Krl}$ 23,16; 1 Krn 12,15; 1 Mch 7,9; Iz 36,2 a także w Jr 19,14. Ze względu na kontekst, treść lub bohaterów poszczególnych wydarzeń cytaty te są odległe albo całkowicie nie przystają do tematyki prezentowanej w omawianym wersecie i jest raczej pewne, że hagiograf, ukazując teologicznie opisywane przez siebie wydarzenia, nie odniósł się do nich. 
władca odcinał i niszczył odczytany fragment słowa Bożego (w. 22-23) (13 $^{13}$ Co przybliża teologicznie oba teksty? Po pierwsze podobne słownictwo kluczowe dzięki obecności obu czasowników (apostellō, histēmi), co jest być może aluzją zamierzoną przez autora Pierwszej Księgi Machabejskiej. Dla wielu specjalistów zajmujących się intertekstualnością w Biblii jest to niewątpliwie najważniejsza cecha budująca pomost między przyrównywanymi wersetami ${ }^{14}$. Pewną trudność interpretacyjną stanowią całkowicie różne konteksty i sytuacje, w których pojawiają się oba czasowniki. Co je jednak o wiele silniej łączy? Punktów stycznych może być kilka:

a) dokument o charakterze zobowiązującym: słowo Boże (Jr) i traktat polityczny wiążący obie strony (1 Mch);

b) obecność podwójnego czynnika władzy po obu stronach dokumentu: Jeremiasz ${ }^{15} /$ Jojakim (Jr) oraz Juda/senat republiki (1 Mch);

c) napięcie między odrzuceniem dokumentu w wyniku arbitralnego działania władcy wyrażonego explicite (Jr) oraz taką samą postawą in potentia (1 Mch);

d) możliwe rozczarowanie postawą jednej ze stron układu/przymierza, która okazuje się niewierna jego postanowieniom, odrzucając je en bloc.

Jeśli więc hagiograf nawiązuje do tego właśnie tekstu, to chce zapowiedzieć, w jaki sposób Rzymianie potraktują zawierany z Żydami układ w momencie, gdy przestanie odpowiadać celom, jakie sami w nim nakreślą. Tekst Pierwszej Księgi Machabejskiej wskazuje bowiem, że to nie żydowscy powstańcy, lecz właśnie senat ułożył postanowienia traktatu. To więc, co dla Żydów staje się conditio sine qua non $w$ ich walce o religijne przetrwanie ${ }^{16}$, dla tamtych może okazać się dokumentem nieposiadającym znaczenia, jeśli zmienią się cele ich polityki lub sytuacja stanie się niezgodna z ogólnymi zamiarami senatu. Zupełnie tak samo postępował właśnie Jojakim drący na strzępy kolejne frazy przepowiadania Jeremiasza.

${ }_{13}$ Por. G.L. Keown, P.J. Scalise, T.G. Smithers, Jeremiah 26-52, WBC 27, Dallas 1995, s. 206.

14 Por. m.in. B.J. Oropeza, Quotes, Allusions, and Echoes: Some Thoughts about What They Mean in Reference to Biblical Scripture, https://www.academia.edu/38547991/Quotes_Allusions_ and_Echoes_Some_Thoughts_about_What_They_Mean_in_Reference_to_Scripture, s. 3 [dostęp: 1.2.2021].

15 Jeśli prorok został potraktowany jako „czynnik władzy”, to w sensie powołania przez Boga (Jr 1,4-10) i przemawiania do ludu na mocy Jego władztwa nad całym narodem wybranym. W Księdze Jeremiasza owo Boże władztwo wyraża się częstym zwrotem ‘ammî („mój lud”), oczywiście na mocy zawartego przymierza na Synaju $(2,13.31 ; 4,11.22 ; 6,14.26 ; 7,12 ; 8,11.19 .21-23$; $9,1.6 ; 12,14.16 ; 14,17 ; 15,7 ; 18,15 ; 23,2.13 .22 .27 .32 ; 30,3 ; 33,24 ; 50,6 ; 51,45)$.

${ }^{16}$ W swej krytycznej analizie tekstu Pierwszej Księgi Machabejskiej S.R. Mandell argumentuje, że Żydzi wierzyli w ważność traktatu, chociaż jego struktura nie była typowa dla układów międzypaństwowych, por. taż, Did the Maccabees Believe that They Had a Valid Treaty with Rome?, CBQ 53 (1991) 2, s. 218-220. 
Tekst prorocki może jednak znacznie wyraźniej naświetlić postępowanie Judy Machabeusza, ponieważ zawieranie układów z pogańskim mocarstwem oznacza de facto „podarcie” i zniszczenie przymierza z Bogiem. Jak wówczas Jojakim, tak obecnie Juda swą arbitralną decyzją anuluje to, co Bóg w swym słowie zawarł dla dobra narodu wybranego. Jak wówczas królowi judzkiemu nie po drodze było z przestrzeganiem słowa Bożego, tak obecnie wodzowi powstania nie pasuje zakaz zawierania przymierzy z poganami, notowany zwłaszcza w Pwt 7,1-2. Nie jest przy tym ważny sposób odrzucenia Bożego słowa, sprzeciwiającego się ludzkim inicjatywom, lecz to, że przywódcy ludu samowolnie odchodzą od wierności prawu przymierza, jakiego lud powinien bezwarunkowo przestrzegać, i przez to odwodzą całą społeczność od zachowywania prawa Bożego. Znamienny jest zapowiadany w imieniu Boga przez Jeremiasza koniec życia niegodziwego króla Judy w 43,30-31 oraz wzmianka historyczna Jr 44,1 (LXX). W pierwszym passusie Bóg ogłasza brak potomka królewskiego na tronie judzkim oraz upokarzającą śmierć władcy niepochowanego w grobowcach królewskich, wystawionego na palące promienie słońca w dzień i zimno nocy ${ }^{17}$. W drugim zaś oznajmia wstąpienie na tron królewski Sedecjasza, stryja Jojakima, w jego miejsce, które stracił wzięty do niewoli. Sedecjasz został mianowany przez Nabuchodonozora, króla Babilonii. Podobnie wyglądała sytuacja po śmierci Judy, po którym władzę objął jego brat Jonatan. Być może w tle całego opisu przywołuje hagiograf pierwowzór takich nieudanych traktatów politycznych zanotowany w Iz 30,1-5. Jego charakterystyką są działania poza wolą Boga i z tej racji całkowicie nieskuteczne; ostatecznie okażą się one pohańbieniem tych, którzy do nich doprowadzali.

Omawiany werset Pierwszej Księgi Machabejskiej może tworzyć aluzję także do wersetu $2 \mathrm{Krl}$ 18,17 (LXX), w którym zwycięski król asyryjski Sennacheryb podczas kampanii w roku 701 przed Chr. spod zdobytego Lakisz posłał (apesteilen) dwóch ze swych wyższych urzędników do Jerozolimy, by zaproponowali obrońcom miasta poddanie się bez walki i przyjęcie zwierzchnictwa asyryjskiego nad Judą. Ci zaś stanęli (estêsan) przy zbiorniku wodnym u bram miasta, chcąc wygłosić odpowiednią, pełną buty i wiary we własną niezwyciężoność mowę ( $2 \mathrm{Krl} 18,17-35)$. Również w tym przypadku zachodzą poważne różnice kontekstowe i sytuacyjne, zwłaszcza kierunek propozycji zawarcia paktu, lecz ważniejsze wydają się związki między obu tekstami:

${ }^{17}$ Hebrajski autor biblijny zawarł tu znamienną grę słów między rzucaniem (hašlēk) w ogień zwoju Jeremiasza przez Jojakima (w. 23) a rzuceniem (mušleket) jego ciała po śmierci na upał dnia (w. 30). Tłumacz grecki zauważył ów literacki zabieg autora hebrajskiego i zawarł tę samą grę słów: (erripten, w. 23), (errimmenon, w. 30), por. także J.A. Thompson, The Book of Jeremiah, NICOT, Grand Rapids 2007, s. 629. 
a) propozycja układu między stroną pogańską i izraelską: władca Asyrii/Ezechiasz ( $2 \mathrm{Krl}$ ) oraz Juda/senat rzymski (1 Mch);

b) obecność czynnika władzy z obu stron;

c) działalność posłów: rabsak (2 Krl) oraz wysłannicy żydowscy (1 Mch);

d) odwrotność okoliczności zawarcia układu: propozycja władcy pogańskiego skierowana do Judejczyków (2 Krl) oraz propozycja Żydów do senatu republiki (1 Mch).

Ostatni z punktów powyższego zestawienia sugeruje rzeczywiste intencje pogan wobec Izraelitów za czasów potęgi asyryjskiej oraz Żydów za czasów Judy Machabeusza. Chodzi wyłącznie o poddanie się dyktatowi silniejszego. Dlatego właśnie pojawia się dla Żydów imperatyw niezawierania takich umów. Jeśli zatem intencją autora Pierwszej Księgi Machabejskiej byłoby zestawienie

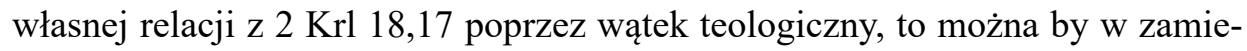
rzeniach Judy dopatrzyć się nieroztropności wynikającej z lekceważenia nauk płynących z historii Izraela, który nigdy ze strony pogan nie mógł spodziewać się korzyści dla siebie. Juda tymczasem zaczął wyraźnie pomijać Boga w polityce zapewniającej bezpieczeństwo swej ziemi, stawiając na niepewny sojusz z pogańską republiką.

Odnotowane przez autora Pierwszej Księgi Machabejskiej połączenie filian kai symmachian (,przyjaźń i przymierze”) wskazuje na jego dobrą znajomość ówczesnych realiów politycznych. Chodzi właśnie o polityczne rozróżnienie między tymi, którzy zobowiązywali się nie przeszkadzać republice w prowadzeniu jej polityki podbojów, a tymi, którzy aktywnie chcieli ją wspomagać $^{18}$. Układy określane tym zwrotem zawierano powszechnie w starożytności ${ }^{19}$. W myśl relacji hagiografa Rzymianie zawierali je, z kim chcieli $(8,1)$, a więc Żydzi nie byli dla nich nikim wyjątkowym.

18 O tym samym celu wspomina również 2 Mch 4,11 opisujący zawieszenie przywilejów, jakimi cieszyli się Żydzi na mocy układu politycznego z Antiochem III Wielkim, por. Ł. Laskowski, Druga Księga Machabejska, NKB.ST XIV/3, Częstochowa 2017, s. 218-219.

19 Informuje o tym połączenie terminologiczne filian kai symmachian $\mathrm{w}$ w. 17 odnoszące do układów politycznych, częstych w starożytności (m.in. Diodor, Bibl. 9,10.5; 16,87.3; 17,49.3; 17,113,1; 20,46.1; Izokrates, Panath. 102.103.162; Pac. 139; Tukidydes, Hist. Pel. 6,34.1; 8,108.4; Flawiusz Arrian, Anab. Alex. 2,14.2; 4,15.2; Polibiusz, Hist. 3,67.7; 3,97.5; 4,6.11; 4,29.2; 7,9.6; $21,20.5 ; 28,8.2 ; 32,10.4)$. 


\section{Cel główny poselstwa}

w. 18: i zdjąć z nich jarzmo, by wiedzieli, że królestwo Hellenów poddaje Izraela $w$ niewole.

Autor ukazuje obecnie jedyny cel żydowskich starań o pakt z republiką. Jest nim chęć zyskania protektoratu i obrony przed atakami monarchii seleuckiej. Własnymi siłami powstańcy nie byli bowiem w stanie przeciwstawić się całej potędze imperium. $Z$ politycznego punktu widzenia było to działanie ze wszech miar korzystne, by zyskać sprzymierzeńca, z którym liczyły się wszystkie ówczesne państwa, permanentnie śląc swych ambasadorów w różnych sprawach wagi państwowej ${ }^{20}$.

Wysłannicy żydowscy nie byli równym partnerem negocjacji. Jednak szukając przede wszystkim militarnego wsparcia dla powstania, mimo woli dawali Rzymowi okazję do mieszania się w spory między władcami seleuckimi a ich niepokornymi poddanymi. Wykorzystując to, republika mogła wpływać na całość polityki monarchii antiocheńskiej pod pozorem obrony zagrożonych mniejszości narodowych. Cel podróży wysłanników został podany przez autora jako tou ārai ton dzygon („zdjąć jarzmo”) z pomocą republiki. Z politycznego punktu widzenia wydaje się jak najbardziej właściwy, jednak w oczach hagiografa faktycznie jest naganny w sposobie swej realizacji, na co wskazuje krótka perykopa Lm 3,25-28 (LXX) zawierająca także ów zapis. Autor stwierdza tam, że Pan dobry jest dla tych, którzy będą Go szukać (w. 25), trwać, oczekując w spokoju ratunku od Niego (w. 26), dźwigając jarzmo (arē dzygon) od swej młodości (w. 27) i w milczeniu znosząc to, co On na nich włożył (w. 28) ${ }^{21}$. Opis ów zarówno co do kontekstu otaczających wersetów, jak i samego w. 27 doskonale naświetla obecną sytuację Żydów w Judei, stanowiąc wskazówkę, gdzie powinni szukać właściwej pomocy. Werset 27 został przywołany jako ewidentne przeciwieństwo obecnych działań Judy i przywódców powstania. Hagiograf posłużył się dwojakim znaczeniem czasownika airō, który w zależności od kontekstu, w połączeniu z rzeczownikiem dzygos (,jarzmo, ciężar") może przyjąć znaczenie „wziąć, podnosić, dźwigać, wieszać”, jak jest to w Hi 6,2 lub Mt 11,2922, lecz także znaczenie przeciwne: „zdjąć, odebrać, zrzucić, zakończyć”, jak właśnie w 1 Mch 8,18 i $13,41^{23}$. Nie tylko jednak przeciwny sens czasownika sta-

${ }^{20}$ Senat umiejętnie je rozgrywał przede wszystkim dla własnych korzyści, co autor natchniony zauważył w swej prezentacji sposobu funkcjonowania republiki.

${ }^{21}$ Por. D. Garrett, P.R. House, Song of Songs, Lamentations, WBC 23B, Nashville 2004, s. $415-416$.

${ }^{22}$ Podobnie także Homer, Il 16.678; 24.583; Od 3.312; 21.18.

${ }^{23}$ Por. także Ajschylos, Eum. 847; Platon, Rep. 578e; Eurypides, El. 942. 
nowi punkt styczny obu passusów, lecz również przeciwny sens kontekstu działań pobożnego Izraelity z Księgi Lamentacji oraz Judy Machabeusza:

a) szukanie/dążenie do Pana (Lm 3,25) oraz szukanie/dążenie do paktu z poganami (1 Mch);

b) oczekiwanie ratunku od Pana $(\operatorname{Lm~3,26)~i~oczekiwanie~ratunku~od~pogan~}$ (1 Mch);

c) dźwiganie własnego jarzma od młodości ( $\operatorname{Lm~3,27)~i~zrzucenie~jarzma~}$ z ludzką pomocą (1 Mch);

d) milczenie i wytrwałość w dźwiganiu ciężaru włożonego przez Pana (Lm $3,28)$ i samowolne odrzucenie ciężaru niewoli politycznej (1 Mch).

Powyższe zestawienie wyraźnie wskazuje na odwrotność działań Judy w relacji do pobożnego i wiernego Bogu wyznawcy. Ich podstawą stało się zakwestionowanie własnego, trudnego losu politycznego jako woli Bożej w karze za dotychczasową niewierność ludu. Tak więc zamiast szukać niepewnego wsparcia u pogan Juda, odczytując poprawnie teologiczny wymiar sytuacji politycznej swego kraju, powinien dźwigać bez własnych inicjatyw ów ciężar, który w ten czy inny sposób wynika z woli Boga. Czy jednak oznacza to politykę defetyzmu i zaniechania dalszej walki o niepodległość? Otóż nie, ponieważ dotychczasowe batalie Judy oraz wcześniejsze jego ojca, Matatiasza, przyniosły wspaniałe efekty ożywienia wiary całego narodu, co ewidentnie nie mogłoby się stać bez Bożego wspomożenia. Obecnie chodzi tylko o to, by nie zastępować Boga przymierzem z niepewnymi poganami, za które trzeba dodatkowo słono płacić darami materialnymi oraz bezwzględną lojalnością polityczną. Wspomniane we wstępie artykułu historyczne i drogie w kosztach pakty między królem judzkim Asą a Ben-Hadadem I, królem Aramu, izraelskim monarchą Achabem a Ben-Hadadem II, następcą tamtego, judzkim królem Achazem a Tiglat-pileserem III, władcą Asyrii oraz królestwem judzkim a Egiptem (Iz 30,1-5) niczego nie nauczyły wodza powstania machabejskiego.

Natomiast pojawiająca się w wersecie nazwa „królestwo Hellenów” (tōn Hellēnōn) odnosi prawdopodobnie do cytatu Iz 9,11a (LXX) wspominającego najazdy wojsk syryjskich od wschodu i Greków od zachodu na Judeę, jako wyraz kary Bożej za niewierność narodu wybranego ${ }^{24}$. Ważną teologicznie rolę odgrywa tutaj kontekst w. 7-11 składający się ze stwierdzeń o wydaniu przez Pana wyroku na Izraelitów (w. 7), który dotknie wszystkich hardych winowajców swego ludu (w. 8). W pysze próbowali się przeciwstawić boskim zrządzeniom, usiłując ludzkim sprytem i przebiegłością trwać przy swych zamiarach (w. 9). W tym jednak miejscu następuje niezrozumiały zwrot akcji w wersji greckiej, zupełnie przeciwnie do brzmienia oryginalnego. W tekście hebrajskim

${ }^{24}$ Por. T. Brzegowy, Księga Izajasza, rozdziaty 1-12, NKB.ST XXII/1, Częstochowa 2010, s. $541-543$. 
bowiem właśnie Pan wzbudził już przeciw buntowniczym Izraelitom pogańskich nieprzyjaciół, którym dał siłę przeciw swemu ludowi (w. 10). Pozwoli to Aramejczykom ze wschodu i Filistynom z zachodu dosłownie ,pożreć”, tzn. całkowicie wyniszczyć Izraela (w. 11a). Taka wersja passusu znakomicie pasowałaby jako komentarz teologiczny do sytuacji opisywanej przez autora Pierwszej Księgi Machabejskiej. W jego ocenie polityka Judy Machabeusza nieroztropnie wiąże się z tymi, którzy z definicji są wrogami Izraela, czy to obecnie — jak Seleucydzi - czy to w przyszłości - jak Rzymianie. Nie można jednym złem próbować zniszczyć drugiego. Jedynie oparcie się na Bogu, wiernemu przymierzu ze swym ludem, pozwoli przetrwać obecną zawieruchę i doczekać czasów pokoju ${ }^{25}$. Aluzja do tekstu hebrajskiego wydaje się jednak mało prawdopodobna, skoro wszędzie w swej księdze hagiograf odwołuje się do wersji greckiej ${ }^{26}$. I to właśnie od w. 10 następuje całkowicie różna od hebrajskiej wersja Septuaginty. Otóż tłumacz zapisal, że Bóg powali wszystkich, którzy ośmielili się wystąpić przeciw górze Syjon i jej mieszkańcom, doprowadzając ich do całkowitego rozproszenia. Tak właśnie stanie się z Syrią atakującą Izraela od wschodu oraz Hellenami, napadającymi naród od zachodu, chcąc go całkowicie wyniszczyć (w. 11). W tym kontekście politykę Judy należałoby ocenić wręcz pozytywnie, ponieważ republika mogłaby stanowić bicz w ręku Boga na dotychczasowych wrogów narodu wybranego ${ }^{27}$. Taka interpretacja nie zgadza się jednak zupełnie $\mathrm{z}$ dotychczasową interpretacją wersetu, podważającą sens zawieranego paktu. Nie zgadza się ona również z całościowym podejściem hagiografa do teologicznego spojrzenia na politykę kolejnych przywódców powstania, coraz bardziej odchodzących od wierności zasadom przymierza, jakie przypominał im umierający ojciec, patriarcha rodu, Matatiasz (2,50-64). Jest całkowicie odwrotnie! By ją poprawnie zrozumieć, należy znów, jak wcześniej, zestawić kontekst zapowiedzi prorockiej i sytuacji opisanej w Pierwszej Księdze Machabejskiej:

${ }^{25}$ Bliską wymowę tego zdania posiada zapowiedź mesjańska w Iz 9,1-6, akcentująca zwłaszcza w w. 1-2 radykalną odmianę sytuacji, której po ludzku nie można już było w żaden sposób uratować, por. T. Brzegowy, tamże, s. 511-513.

${ }^{26}$ Wiadomo, że najprawdopodobniej istniała wcześniejsza wersja hebrajska Pierwszej Księgi Machabejskiej i jeśli jej autor również stosował aluzje intertekstualne, to mógłby z powodzeniem wykorzystać teologię pierwotnego brzmienia Iz 9,10-11a. Najnowsze badania potwierdzają istnienie hebrajskiego pierwowzoru księgi, por. m.in. G. Darsham, The Original Language of 1 Maccabees: A Reexamination, BN (NF) 182 (2019), s. 91-110.

27 Teologia pogan jako bicza w ręku rozgniewanego Boga jest bardzo dobrze poświadczona na kartach Starego Testamentu, czego przykładem jest zwłaszcza zapowiedź Iz 10,5-19 zawierająca dwa ważne składniki: karę za niewierność dla Izraela oraz oznajmienie zniszczenia samych pogan za ich swoistą „,nadgorliwość” w walce z ludem Pana, por. H. Wildberger, Isaiah 1-12: A Continental Commentary, Minneapolis 1991, s. 416-433. 
a) wyrok Boży na Izraela nieznany chwilowo winowajcom (Iz 9,7/1 Mch);

b) poznają go w swoim czasie hardzi mieszkańcy Izraela (Iz 9,8) jak i Juda, gdy przyjdzie mu zginąć w walce z nieprzyjaciółmi, oraz niewierni Bogu powstańcy, którzy wspierali go w działaniach politycznych (1 Mch);

c) samowolne i pyszne zastąpienie dawnych zniszczeń wojennych lepszymi zabezpieczeniami (Iz 9,9) i samowolne zastąpienie Boga Izraela układem $\mathrm{z}$ republiką rzymską (1 Mch);

d) przeciwdziałanie Boga powodującego powalenie i rozproszenie wrogów Judy walczących z obu stron kraju i działania Jonatana, następcy Judy, wiernego Bogu w początkach swego przywództwa, pokonującego wielonarodowe imperium seleuckie (1 Mch).

Układ faktów opisanych w Pierwszej Księdze Machabejskiej każe sięgnąć już po nowe czasy przywództwa Jonatana, po śmierci Judy, ocenionego przez hagiografa na wzór krnąbrnych mieszkańców północnego królestwa Izraela, którzy zostali poddani pod władzę Asyrii (Iz 9,8-9) ${ }^{28}$. Wzmianka o Hellenach w greckiej wersji Iz 9,11 może nawiązywać do powygnaniowego wersetu Za 9,13 (LXX) zawierającego proroctwo o królestwie Judy i Izraela, które zwyciężą właśnie Hellenów, ponieważ sam Pan da im wystarczające ku temu siły. Ten właśnie moment jest decydujący w zrozumieniu sensu przesłania greckiego tekstu Izajasza: Syjon nie ma potrzeby ratować siebie samego, lecz winien zdać się całkowicie na Jego pomoc wynikającą z wierności przymierzu ${ }^{29}$.

Skoro zatem Bóg sam dokona spustoszenia w armiach nieprzyjaciół swego ludu, tym bardziej nie należy wiązać się politycznie z kimkolwiek spośród nich. Nawet wówczas gdy przez moment są górą, gdy bezlitośnie ciemiężą lud, nigdy nie będą w stanie powalić go całkowicie, ponieważ Bóg na mocy przymierza będzie ratował Izraela, który przez cierpienia prześladowań i ucisku odpokutuje swe winy wobec Niego. Poganie zaś zostaną całkowicie wytępieni za chęć wyniszczenia narodu wybranego ${ }^{30}$. Jeśli więc Bóg postanowił taką sytuację, to błędem jest poszukiwanie jej rozwiązania poza Nim, jak tego chce obecnie Juda. Oba teksty Lm i Iz znakomicie się dopełniają co do obecnej sytuacji w Judei

${ }^{28}$ Por. G.V. Smith, Isaiah 1-39: An Exegetical and Theological Exposition of Holy Scripture, NAC 15A, Nashville 2007, s. 245-246.

${ }^{29}$ Egzegeci nieprzypadkowo zwracają uwagę na wagę terminu jāwān („Grecja”), który historycznie nabierze militarnego znaczenia znacznie później, po wojnach Aleksandra Wielkiego, zajęciu całej Azji i Egiptu i nastaniu epoki hellenistycznej. Prorok Zachariasz wygłasza swe orędzie w imieniu Boga, zwiastując nadejście nowych czasów, z którymi właśnie Machabeusze zetkną się najbardziej. Wielu uczonych przychyla się do wniosku, że zapowiadane w Za 9,13 zwycięstwo Boga, inaugurujące Jego królestwo, dokonało się w roku 165 przed Chr., gdy Juda zdobył Syjon i odbudował kult świątynny, por. G.L. Klein, Zechariah: An Exegetical and Theological Exposition of Holy Scripture, NAC 21B, Nashville 2008, s. 277-278.

${ }^{30}$ Por. Iz 47,6; Jr 51,24.34-35; Ez 25,3-7.12-17; 26,2-6; Za 1,14-15; 12,9. 
jako skutku niewierności Żydów swemu Bogu, a zarazem podają wskazówki wyjścia z niej.

Dokładnie w tym samym kierunku wiedzie użycie czasownika katadouloō („poddaję w niewolę, zniewalam”) w prezentacji monarchii seleuckiej usiłującej utrzymać w niewoli (katadouloumenous) swą zbuntowaną prowincję. Czasownik jest prawdopodobnie echem wyroczni prorockiej Jr 15,14 (LXX). Niezwykle trudny do interpretacji jest kontekst Jr 15,12-14, odcinający się wyraźnie od poprzedzającej go skargi proroka na jego okrutny los mimo wszelkich zabiegów, jakie przedsiębrał w celu ratowania nieposłusznego ludu królestwa judz-

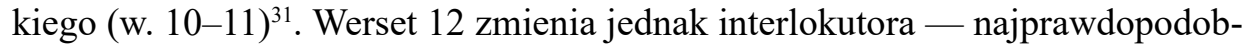
niej staje się nim sam rozgniewany Bóg, który wydaje się nie słuchać narzekań swego herolda. Zadaje On wpierw retoryczne pytanie o siłę oręża, w którym Judejczycy pokładają nadzieję (w. 12). Odpowiedź może być jednoznaczna, choć nie pada w tekście zapewne dlatego, że jest tak oczywista. Stąd kolejne zapowiadane decyzje Boga, że moc ludu, jego skarby wyda On na splądrowanie jako skutek nieprawości we wszystkich terytoriach należących do Judy (w. 13). Sam zaś lud zostanie oddany w niewolę (katadoulōsō) nieprzyjaciołom w kraju, którego on nie zna, ponieważ ogień został rozniecony gniewem Pana i zapłonie nad upartymi w swej głupocie Judejczykami (w. 14) ${ }^{32}$. Wszystkie trzy wersety doskonale oddają teologiczną ocenę sytuacji, jaką pragnie obecnie podać czytelnikowi autor Pierwszej Księgi Machabejskiej. Kolejny wykaz cech podobnych pozwoli zauważyć bliską relację między oboma kontekstami:

a) Boże pytanie o moc jakiegokolwiek oręża przeciw Jego decyzjom $(\mathrm{Jr}$ 15,12) jako komentarz do polityki Judy Machabeusza zbyt mocno dowierzającego siłom militarnym republiki i uczciwości senatu wobec Judei (1 Mch);

b) zapowiedź ograbienia mieszkańców z ich dobytku jako kara za krnąbrność w postawie nieposłuszeństwa (Jr 15,13) i zapowiedź prześladowań w kraju po przegranej bitwie pod Elasa lub - w dalszej perspektywie - w wyniku spodziewanych w przyszłości działań Rzymian w Judei $(1 \mathrm{Mch})^{33}$;

c) przeznaczenie ludu do niewoli jego wrogom w nieznanym kraju jako skutek gniewu Bożego za upór $(\mathrm{Jr} 15,14)$ i poddanie ludu w ponowną nie-

${ }^{31}$ Werset 15 powraca znów do mowy proroka błagającej obecnie o wspomnienie przez Boga wszelkich niesprawiedliwości, jakie prorok wycierpiał od swych przeciwników.

${ }^{32}$ Por. zgodność tu z oryginałem hebrajskim, J.A. Thompson, The Book of Jeremiah ..., s. 391392.

${ }_{33}$ Dokładnie tak samo działo się wówczas, gdy król Achaz układał się z Tiglat-pileserem III (2 Krl 16,7-9; 2 Krn 28,16-21), a 30 lat później Asyryjczycy stanęli u wrót Jerozolimy i tylko cudowna interwencja Boga uratowała miasto (2 Krl 19,35). 
wolę seleucką lub w przyszłości rzymską, jako skutek uporu w forsowaniu paktu z Rzymianami (1 Mch) ${ }^{34}$.

Werset 12 można zinterpretować dwojako: Juda uwierzył do tej pory zbyt mocno w możliwości własnego oręża po wielu wygranych bitwach z wojskami seleuckimi i zaprzestał poszukiwać pomocy u Pana, zapominając, że tylko On daje stosowną siłę ${ }^{35}$. Uświadomiwszy sobie jednak własną niewystarczalność, udał się po pomoc do kolejnego państwa pogańskiego, zamiast zdać się na pomoc Boga, zawsze wiernego przymierzu. Znów, jak poprzednio własnym, tak obecnie zaufał siłom militarnym najpotężniejszego gracza na politycznej scenie ówczesnego świata. Jeśli przywoływany wcześniej passus Iz 30,1-5 mówi o zawstydzeniu, jakiego doświadczą Judejczycy, opierając się na słabym i bezsilnym Egipcie, to obecnie sytuacja zdaje się odwrotna: Juda opiera się na potędze niezwyciężonej w bojach republiki rzymskiej. Skoro tak, to zawstydzenie przyjdzie z innego powodu: obecni sprzymierzeńcy w świetle zapowiedzi Jeremiasza, staną się w przyszłości największym ciemiężycielem narodu wybranego ${ }^{36}$. Trudno obecnie ocenić, czy autor natchniony wieści już przyszłość, jakiej Judejczycy doświadczą z rąk Rzymian za kilkadziesiąt lat od momentu, gdy Pompejusz Wielki zawładnie po raz pierwszy Palestyną. Najprawdopodobniej jednak hagiograf aż tak daleko nie sięga, ponieważ nie chce wieścić się klasycznym prorokiem Izraela. Sięga raczej po wielowiekowe doświadczenie Izraela, który

${ }^{34}$ Jednym $\mathrm{z}$ ważnych osiągnięć analizy intertekstualnej jest nie tylko możliwość zestawiania poszczególnych wersetów w celu odszukania możliwych związków teologicznych, będących intencją autora natchnionego. Chodzi także o możliwość budowania tych związków między autorem natchnionym a czytelnikiem. To właśnie czytelnik jest uprawniony do szukania własnych, byleby uprawnionych, tzn. zgodnych z przesłaniem hagiografa, wniosków teologicznych, por. K. Nielsen, Intertextuality and Biblical Scholarship, SJOT 4 (1990) 2, s. 90-92. Szerzej tematem tym zajął się także J.M. Pucci, The Full-Knowing Reader: Allusion and the Power of the Reader in the Western Literary Tradition, New Haven 1998. M. Fishbane nazwał ów proces ,egzegezą agresywną”, która „zajmuje się przede wszystkim wykorzystaniem pełnego zakresu odziedziczonego traditum [czyli materiału do dalszego przekazania i rozpatrzenia — przyp. J.N.], w celu uzyskania nowych teologicznych spostrzeżeń, postaw i spekulacji”. Owa egzegeza agresywna dotyczy „ukrytych i nieoczekiwanych znaczeń” w traditum i „sprawia, że ten potencjał staje się faktyczny”, por. M. Fishbane, Biblical Interpretation in Ancient Israel, Oxford 1988, s. 283.

35 Wniosek ów nasuwa się mimo wcześniejszej, znakomitej deklaracji Judy, że dla Boga nie ma znaczenia wielkość sił ludzkich. Daje On tym większą pomoc człowiekowi, im mniejszą siłą dysponuje wierny Mu wyznawca (1 Mch 3,18-19). Tymczasem jednak Juda zdecydował się samowolnie zaatakować jerozolimską Akrę, pokładając zapewne zbyt wielką ufność w siłach swego wojska. Zmuszony do odstąpienia od ataku (1 Mch 6,32) musiał skupić się na walce z wojskami Antiocha V. Po raz pierwszy nie udało mu się utrzymać stanu posiadania, co poskutkowało koniecznością wycofania się z miasta. Analiza całościowa sytuacji, por. J. Nawrot, Dlaczego oni zwyciężaja? Teologiczna ocena judejskiej kampanii Antiocha V Eupatora w 1 Mch 6,47-54, SG 31 (2017), s. 85-103.

${ }^{36}$ Na podobieństwo zapowiedzi Ez 16,37; 23,9.22-26. 
po poganach nie mógł się spodziewać relacji przyjaznych. W długim szeregu ciemiężycieli narodu wybranego wymienić należy takie potęgi, jak Egipt, Asyrię, Babilonię wraz z pomniejszymi narodami ościennymi, które nie szczędziły mu trudów, wojen i prześladowań. Właśnie to doświadczenie powinno dominować w politycznych zabiegach Judy Machabeusza, wodza walki przeciw kolejnej potędze pogańskiej, jaką do tej pory jest imperium seleuckie.

Pojawia się także uwaga, że imperium seleuckie usiłuje poddać Israēl douleiā („Izraela niewoli”). Oto lud doświadcza ciężaru samotnej walki z silniejszymi nieprzyjaciółmi, ponieważ ostatecznie tylko Bóg może prawdziwie wyzwolić swój lud z wszelkiej niewoli, jak to zapowiadał przez swych proroków ${ }^{37}$. Nie uczyni tego żadna pomoc ze strony pogan. Historyczne doświadczenie Izraela powinno tu być wystarczającym argumentem.

\section{Droga do stolicy republiki}

w. 19: Udali się zatem do Rzymu a droga byta bardzo daleka, weszli do senatu, zdeklarowali się i powiedzieli:

Stwierdzając w w. 19, że droga do Rzymu była daleka, autor nie chce uświadamiać czytelnikowi jedynie dystansu dzielącego Jerozolimę od stolicy republiki. Zwrot eporeuthēsan eis... (,udali się do...”) może stanowić aluzję do prorockiego tekstu Jon 3,3 (LXX), w którym konstrukcja eporeuthē eis — „udał się do" Niniwy - służy głoszeniu nawrócenia wielkiemu miastu ${ }^{38}$. Jeśli autor nawiązuje do tego właśnie miejsca, to w kolejnym porównaniu kontekstowym chce ukazać przeciwieństwo sytuacji:

a) posyłający: Bóg (Jon) i inicjatywa własna powstańców (1 Mch);

b) adresat misji: podróż do Niniwy (Jon) i podróż do Rzymu (1 Mch);

c) cel misji: pomoc poganom, aby uratować im życie (Jon) i zdobywanie u nich pomocy (1 Mch);

d) charakter misji: głoszenie słowa Bożego poganom w celu ich nawrócenia (Jon) i sfera czysto świecka w zawarciu układu politycznego (1 Mch).

Jakiekolwiek ewentualne kontakty z poganami powinny być więc poprzedzone bezwzględną i silną wolą wierności $B \operatorname{su}^{39}$ bez względu na drogę, jaką

37 Por. zapisy Wj 6,6; Sdz 6,8; Jr 41,13 (LXX).

38 Por. D. Stuart, Hosea - Jonah, WBC 31, Waco 1987, s. 482, 486-488.

${ }^{39}$ Podobną konstrukcję poreusometha en onomati kyriou theou hèmōn zawiera także prorocki cytat Mi 4,5. 
obiorą sobie inne ludy ${ }^{40}$. Przeciwnie, to inne narody powinny przybyć (poreusontai) do Jerozolimy, by poznawać prawo Pańskie i kroczyć Bożymi drogami [Mi 4,2; Iz 2,3 (LXX)].

Dalsza uwaga, że droga do Rzymu była bardzo długa (hodos polle sfodra) sprawia wrażenie chęci ukazania wielkości wysiłku, jaki musieli podjąć posłańcy, by dotrzeć do celu. Dwa pierwsze wyrazy nawiązują prawdopodobnie do wersetu

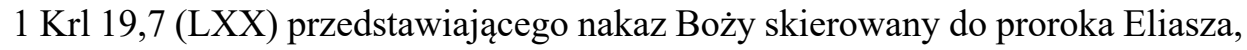
by udał się w długą drogę, przy czym wystarczył mu wówczas skromny posiłek dający jednak moc przejścia 40 dni i nocy ${ }^{41}$. Kontekst $1 \mathrm{Krl}$ 19,1-8, wskazujący znów na przeciwieństwo sytuacji, posiada swe następujące cechy ${ }^{42}$ :

a) prześladowanie Eliasza przez Achaba i Jezabel (1 Krl 19,1-3) i prześladowanie Żydów przez imperium seleuckie (1 Mch);

b) pragnienie śmierci jako końca trudów walki $(1 \mathrm{Krl} \mathrm{19,4)} \mathrm{i} \mathrm{pragnienie}$ zyskania pomocy w walce (1 Mch);

c) pierwsza angelofania we śnie z nakazem spożycia przygotowanego cudownie posiłku (1 Krl 19,5-6) i wykluczenie Boga ze starań o pokój w kraju (1 Mch);

d) druga angelofania z nakazem wyruszenia w długą drogę [polle (...) hodos] do wyznaczonego celu (1 Krl 19,7-8) i inicjatywa własna Judy realizująca wyznaczony samodzielnie cel (1 Mch).

Podobne są zatem warunki prześladowania słusznej sprawy, podejmowane zostają jednak całkowicie różne inicjatywy. Eliasz oparł się wyłącznie na Bogu, doświadczając słabości ciała, nie widząc możliwości przeciwstawienia się ogromowi trudności, z jakimi miał do czynienia. Wyraźnie nie miał też ochoty podejmowania czegokolwiek na własną rękę, pragnąc z wyczerpania nawet śmierci. Tymczasem Juda, poczuwszy wiatr w żaglach, zapragnął samowolnie pokierować losami walki o niepodległość kraju, zapominając, że wszystko zależy od Boga trzymającego nici wydarzeń w swoim ręku. Drugim elementem kontrastu jest obecność u boku proroka anioła Bożego wspomagającego człowieka posiłkiem. Bez niego prorok nie był w stanie kontynuować ani dalszej drogi, ani w ogóle swej misji. Pozwoliło to Bogu całkowicie odnowić wiarę proroka i jego przekonanie o bliskości Tego, który narażając swego sługę na trudy, nie przestaje jednak się nim stale opiekować ${ }^{43}$. Juda — odwrotnie — nie oczekiwał już

${ }^{40}$ Nakaz wierności Bogu całego ludu, wyrażony zwrotem poreusontai hekastos tēn hodon autou notuje tekst Pwt 30,16.

${ }^{41}$ Por. J.B. Łach, Księgi 1-2 Królów. Wstęp - przekład z oryginatu - komentarz - ekskursy [w:] PŚST, t. IV, cz. 2, Poznań 2007, s. 339.

${ }_{42}$ Szczegółowy podział materiału biblijnego, por. B.O. Long, 1 Kings with an Introduction to Historical Literature, FOTL IX, Grand Rapids 1984, s. 196-197.

${ }^{43}$ Por. P.R. House, 1-2 Kings: An Exegetical and Theological Exposition of Holy Scripture, NAC 8, Nashville 1995, s. 222. 
od Boga niczego, ponieważ odpowiednią dla siebie pomoc znalazł w przymierzu z pogańskim imperium ${ }^{44}$. Posłowie Judy do Rzymu nie mogą zatem spodziewać się Bożego wsparcia $\mathrm{w}$ realizacji swego przedsięwzięcia, skoro podejmują drogę nie na Jego rozkaz, lecz wyłącznie z ludzkiej inicjatywy.

Równie ciekawa może być jednak aluzja hagiografa do wersetu Joz 9,13 (LXX), zawierającego cały zestaw wskazanych w 1 Mch 8,19 terminów. Przybywszy do Jozuego, posłańcy z Gabaonu wspomnieli o bardzo długiej drodze (pollēs hodou sfodra), jaką rzekomo przebyli, by zawrzeć z nim przymierze. Ważny jest tu znów kontekst wydarzenia, opisany szeroko w passusie Joz 9,3-15 (LXX), stanowiącym bliski Pierwszej Księdze Machabejskiej kontekst paktu politycznego, jednak ponownie na zasadzie kontrastu postępowania przy jednoczesnych podobieństwach sytuacyjnych:

a) wiadomości zaczerpnięte przez Gabaonitów o sukcesach Jozuego (Joz 9,3) i wiadomości Judy o Rzymianach (1 Mch 8,1-16);

b) różna sytuacja petenta: Gabaonici (= poganie!) proszący Izraelitów o zawarcie układu (Joz) i Żydzi proszący Rzymian o zawarcie układu (1 Mch);

c) podstęp pogan wobec Izraelitów (Joz 9,4-13) i szczera wola Żydów nawiązania paktu z poganami (1 Mch);

d) brak konsultacji Izraelitów z Bogiem w podejmowaniu decyzji (Joz 9,14) i taki sam brak konsultacji Judy z Bogiem w podejmowaniu decyzji (1 Mch);

e) zgoda Jozuego na zawarcie przymierza (Joz 9,15) i taka sama zgoda senatu rzymskiego (1 Mch 8,21-32).

$\mathrm{Z}$ powyższego zestawienia wynika, że powstańcy popełnili dwa podstawowe błędy, których mogli uniknąć, gdyby wnikliwiej wpatrywali się w historię swego narodu. Pierwszym z nich był brak radzenia się Boga w sytuacjach tak ważnych jak zawieranie przymierza z poganami. Jeśli można założyć, że Jozue popełnił błąd raczej przez nieuwagę lub zapomnienie, to Juda działał już jednak świadomie, pomijając Boga w swojej polityce. Drugim błędem było naiwne przekonanie, że poganie okażą się uczciwi w zawieraniu układów z Żydami. Łatwowierność Izraelitów z otoczenia Jozuego wobec zapewnień pogan zaowocowała niemożnością uskutecznienia nakazu Pwt 7,1-2. Podobnie Juda rychło przekona się, że nie można polegać na zapewnieniach senatu rzymskiego, gdy samotnie będzie walczył przeciw armii imperium seleuckiego i zginie.

${ }^{44} \mathrm{~W}$ omawianym wersecie Pierwszej Księgi Machabejskiej czytelnik może odnaleźć pewne

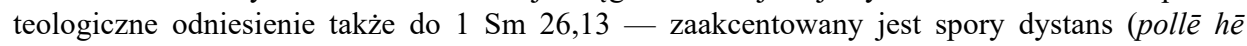
hodos) dzielący Dawida nękanego przez Saula. Możliwą interpretacją tego zestawienia jest postulat trzymania się prześladowanego od prześladującego w możliwie jak największej odległości i poczucie bliskości wspomagającego Boga, nie zaś szukanie zbliżeń z innymi, potencjalnymi ciemiężycielami. 
Teologicznie ważny wydaje się również zapis, że posłowie żydowscy, wchodząc do senatu apekritēsan kai eipon („zwrócili się i rzekli”). Prorocka wyrocznia Iz 14,10 (LXX) wieści przyszły upadek nieznanego imperium, stojącego obecnie u szczytu swej potęgi ${ }^{45}$. Bliższy kontekst w. $4 \mathrm{~b}-21$ stanowi poetycka elegia nad upadłym tyranem z wyraźnie brzmiącym szyderstwem z losu tego, który sam siebie widział jako centrum świata i był przekonany, że wszystko jest dla niego możliwe ${ }^{46}$. W dość skomplikowanej budowie literackiej utworu można wyróżnić cztery strofy: w. 4b-8; 9-11; $12-15$ oraz 16-21. Najbliższe obramowanie omawianego wersetu tworzy jednostka w. 9-11, której tematem wiodącym jest zstąpienie zabitego króla do Szeolu, połączone z przyjęciem zgotowanym mu przez zamieszkujące go bezsilne cienie wcześniej padłych bohaterów, królów i wielmożów ${ }^{47}$. Poemat przekonuje, że żadna potęga państwowa nie będzie trwała wiecznie, ponieważ nad wszystkim swą władzę sprawuje jedyny Bóg. Jak uprzednio padały inne imperia, których władcy obecnie przebywają w Szeolu, tak również upadnie wielki monarcha, co właśnie ci umarli zaczną mu zwiastować (apokrithēsontai kai erousin, 14,9). Aluzja podobieństwa między Babilonem a Rzymem, dokonana przez hagiografa, wieści przyszły los imperium znad Tybru na podobieństwo tego, co spotkało wcześniej imperium znad Eufratu. Oto także Rzym stał właśnie u szczytu swej mocarstwowości, nie zamierzając respektować paktu z Żydami. Dla potężnej republiki nie stanowili oni partnera równorzędnego. Tymczasem właśnie $\mathrm{z}$ woli Boga taka postawa stanie się powodem ich późniejszego upadku, bowiem nawet jeśli naród wybrany popełnia błędy i odchodzi od wierności swemu Bogu, to na mocy przymierza ujmie się On za nim i wymierzy sprawiedliwość tym, którzy go zwiedli, oszukali i wykorzystali ${ }^{48}$. Poganie natomiast zginą, czego wcześniej doświadczyły Egipt, Asyria i Babilonia. Paradoks tymczasem uwidacznia się w tym, że przybywający $\mathrm{z}$ prośbą o pomoc Żydzi apekritēsan kai eipon do senatu, stając się $\mathrm{w}$ ten sposób mimowolnymi zwiastunami przyszłej klęski wielkiego imperium. Dla Judy i powstańców pamięć o tym powinna stać się ważnym ostrzeżeniem przed politycznym wiązaniem się z niepewnymi siłami pogańskimi.

Poemat w Księdze Izajasza, zdaniem części egzegetów, zawiera jednak również ważne elementy funkcjonowania samej wspólnoty żydowskiej, zwłaszcza napięcia istniejące $w$ jej wnętrzu między różnymi grupami społecznymi. Atakowani są zwłaszcza pełni arogancji i pychy niegodziwcy, przekonani, że wszystko

${ }^{45}$ Groźba wyrażona konstrukcją apokrithēsontai kai erousin, będąca kalką zwrotu hebrajskiego wa ‘̆nn̂े wajjom ${ }^{e}$ rû, por. G.V. Smith, Isaiah 1-39..., s. 314.

${ }^{46}$ Por. L. Stachowiak, Księga Izajasza I 1-39. Wstęp - przektad z oryginalu - komentarz, [w:] PŚST, Poznań 1996, s. 283-284.

${ }^{47}$ Por. T. Brzegowy, Księga Izajasza. Rozdziaty 13-39, NKB.ST 22/2, Częstochowa 2014, s. 69.

${ }^{48}$ Por. m.in. J1 4,1-8; So 2,8-10; Iz 10,5-19; 52,1-6; Ez 25,12-17; 39,7. 
im wolno (w. 4b.12-14.16-17). Widoczny jest również uderzający w winowajców bat (w. 5-6) oraz spektakularne odwrócenie obecnej sytuacji, gdy świetność, potęga i pewność siebie zamieniają się w biedę, beznadzieję i śmierć. Obecność terminów $r^{e} s^{a} \bar{a}$ 'îm, „nikczemnicy” (w. 5) oraz $m^{e} r e \bar{e} \hat{\imath} m$, ,złoczyńcy” (w. 20 ${ }^{49}$ oznacza tradycyjnie niegodziwych mieszkańców królestwa południowego $^{50}$. Jeśli $\mathrm{z}$ tego punktu widzenia spojrzeć na okres powstania, to satyra mogłaby odnosić się także do postępowania Judy, zbyt dufnego co do możliwości własnych i swojej armii, widzącego siebie jako przywódcę ludu na podobieństwo innych władców i dzięki zawieranym paktom polityczno-militarnym mającego apetyt na bycie zaliczonym do wielkich tego świata. Gorzkie rozczarowanie przyjdzie już niedługo, gdy republika zupełnie zlekceważy własne zobowiązania, a on sam przejdzie do Szeolu po utracie życia w ostatniej bitwie swego przywództwa. Wówczas słowa posłów żydowskich do senatu można by interpretować jako swoisty łabędzi śpiew w imieniu wodza, który wkrótce sam legnie pośród umarłych. Wraz z nim umrze tak misternie tkany projekt wielkiego sprzymierzenia politycznego i przyjaźni, które z braku Bożego wsparcia okazały się wyłącznie pustym, niezrealizowanym marzeniem.

\section{Mowa posłów do senatu}

w. 20: Juda Machabeusz, jego bracia i lud Judejczyków postali nas do was byśmy ustanowili z wami przymierze i pokój, byśmy zostali zapisani jako wasi sprzymierzeńcy i przyjaciele.

Treść poselstwa wygląda jak typowa prośba petenta do zwierzchnika. Do ustawienia się w kolejce do senatu zmusiła Żydów groźna sytuacja w prowincji. Potrzebowali pomocy Rzymu. Można się spodziewać, że z tego powodu układ będzie wygodniejszy dla republiki niż dla proszących. Mowę posłów rozpoczyna prezentacja autorów inicjatywy zawarcia paktu, którymi są przywódcy powstania i cały lud. Mając świadomość wrogiego Judzie środowiska Alkimosa w Jerozolimie, należy sformułowanie plēthos tōn Ioudaiōn traktować zapewne jako możliwie najszerszą reprezentację tych, którzy opowiedzieli się za walką z hellenizacją kraju. Chodzi więc o zaznaczenie najszerszego konsensusu społeczności żydowskiej jako tych, którzy wysłali (apesteilan) ich z misją. Wzmianka o „ludzie” ma z pewnością dodać reprezentatywności propozycji żydowskiej, zważywszy na to, że Juda nie posiadał zgody najważniejszego urzędu arcyka-

\footnotetext{
49 Por. Ps 26,5; 37,9-10; Prz 4,16-17; 24,18-19.

${ }^{50}$ Por. J. Vermeylen, Du prophète Isaïe à l'apocalyptique. Isaïe I-XXXV, miroir d'un demimillénaire d'expérience religieuse en Israël, t. 1, Paris 1977, s. 295.
} 
płana, zwierzchnika religijnego w kraju, będąc z nim w stałym konflikcie. Mimo że plēthos tōn Ioudaiōn występuje w Biblii greckiej tylko w tym wersecie, Septuaginta notuje passus $2 \mathrm{Krl} \mathrm{7,12-14} \mathrm{(LXX)} \mathrm{zawierający} \mathrm{pokrewny} \mathrm{zwrot}$ plèthos Israēl (w. 13). Jego kontekstem jest niepewność sytuacji, w której znalazł się król Izraela w walce z syryjskim nieprzyjacielem pośród powszechnego i dokuczliwego głodu. Pozostałe przy życiu po walce konie wyprawiono (aposteloumen) z dwoma jeźdźcami, by sprawdzili, co dzieje się w obozie przeciwnika ${ }^{51}$. Układ w. 12-14 w Drugiej Księdze Królewskiej dobrze odpowiada sytuacji Judy Machabeusza i powstańców w Pierwszej Księdze Machabejskiej:

a) oznajmienie trudnego położenia wojsk izraelskich i możliwego podstępu wroga (w. 12) i poselstwo do Rzymu z oznajmieniem sytuacji w Judei (1 Mch);

b) propozycja wysłania zwiadowców jako odpowiedź na sytuację (w. 13) i poselstwo do Rzymu (1 Mch);

c) decyzja uczynienia w myśl propozycji (w. 14) i decyzja senatu wspomożenia Żydów (1 Mch).

W tekście Drugiej Księgi Królewskiej brakuje wprawdzie wysłannikom interlokutora, lecz schemat działania bohaterów pozwala się doskonale wykorzystać właśnie w sprawie poselstwa do Rzymu: zawiadomienie o trudnej sytuacji, propozycja wysłania posłów oraz jej realizacja. Ważne jest jednak w tym miejscu zaznaczenie, że cała sytuacja rozgrywa się w atmosferze najwyższego niepokoju o spodziewane skutki całego przedsięwzięcia. Podobnie wyprawa dwóch posłańców Judy do Rzymu nosi w sobie wysokie ryzyko niepewności, ponieważ jest ewidentnym działaniem poza wolą Bożą.

Celem poselstwa było ustanowienie „sojuszu” (symmachia) i „pokoju” (eirēnē) z republiką jako sedno negocjowanego przymierza ${ }^{52}$. Wysoki stopień niepewności potwierdza m.in. Strabon, pisząc, że pokój (eirēnē) i przymierze (symmachia) od czasów, gdy Rzymianie przejęli kontrolę nad wieloma prowincjami, mogą dokonywać się jedynie za ich zgodą lub jeśli odpowiada to ich oczekiwaniom (Geogr. 14,3.3). Uwaga greckiego geografa, historyka i podróżnika celnie odmalowuje wpierw dysproporcję między oboma partnerami paktu politycznego, potem zaś dobrowolne zdanie się Żydów na łaskę lub niełaskę senatu i pozwolenie na całkowite manipulowanie swym losem w interesie republiki. Końcowe połączenie symmachos i filos odnosi zarówno do założeń traktatu, które ukazane zostaną w kolejnych wersetach, w piśmie senatu do Żydów (w. 23-32), jak i do wcześniejszych zwyczajów rzymskich, które autor odno-

${ }^{51}$ Por. J.B. Łach, Księgi 1-2 Królów..., s. 422.

52 Oba terminy stanowią część uzgadnianych traktatów i znane są literaturze pozabiblijnej, por. Tukidydes, Hist. Pel. 4,19.1; Polibiusz, Hist. 4,15.8-9; 6,14.10-11; Plutarch, Nic. 10.2-3; Arat. 33.1; Tit. 5.6; Flawiusz Arrian, Anab. Alex. 3,24.5; Diodor, Bibl. 19,75.6. 
tował (w. 11.17). Są to tytuły stricte polityczne, doskonale znane w piśmiennictwie greckim $^{53}$. Poza takim samym kontekstem Pierwszej Księgi Machabejskiej Septuaginta nie notuje tego typu zwrotów ${ }^{54}$. Nie można jednak przeoczyć tego, że wszystko dzieje się w niezgodzie z jedynym dopuszczalnym z religijnego punktu widzenia przymierzem, jakim jest to, które niegdyś zostało zawarte między Bogiem a Jego ludem na Synaju (Pwt 7,1-2). Chociaż nie dotyczy ono ludów i krajów najbliższych Izraelowi, zdecydowanie naraża zarówno przywódców powstania, jak i cały lud na ponowną utratę wiary przez odrzucenie wierności Bogu Izraela i poddanie się prawom wyznaczonym przez kolejne imperium pogańskie.

\section{Podsumowanie}

a) elementy analizy intertekstualnej, oparte przede wszystkim na tych samych konstrukcjach terminologicznych, wydają się najodpowiedniejsze w celu ustalenia głębszego związku między poszczególnymi wersetami Septuaginty;

b) tekst grecki Starego Testamentu może zawierać własne relacje intertekstualne, niezależnie od oryginału hebrajskiego, jak jest to w wypadku 1 Mch 9,18 i Iz 9,11;

c) mimo tak zdawkowego obszaru badań nad tekstem Pierwszej Księgi Machabejskiej, co jest związane z zakresem tematycznym artykułu, wydaje się, że dla autora Księgi najważniejszą rolę w zawiązaniu relacji intertekstualnej gra nie tylko celowy związek terminologii, lecz przede wszystkim kontekst dziejących się wydarzeń; w każdej z omawianych relacji tekstowych właśnie bliskość tego kontekstu wychodzi na pierwsze miejsce;

d) decydująca obecność kontekstu przywoływanych wersetów w aluzjach intertekstualnych sprawia, że nie tyle sam związek frazeologiczny, ile ich milieu teologiczne stoi u podstaw oceny postępowania głównego bohatera, czynionej przez hagiografa;

e) dla odkrycia głębszego spektrum teologicznego powiązanych aluzją wersetów hagiograf może posłużyć się więcej niż jednym tekstem, który przywołuje aluzja, np. 1 Mch 8,17 oraz Jr 43,21 i 2 Krl 18,17 w zesta-

${ }^{53}$ Związek frazeologiczny symmachos i filos wskazuje na ich polityczny sens (m.in. Ajschines, Leg. 2.9; Ctesiph. 3.61; Demostenes, Leg. 143. 334; Lep. 59; Eurypides, Phoen. 535; Platon, Men. 94d; Plutarch, Alc. 26.1; Ksenofont, Anab. 1,3.6; Cyrop. 6,4.13; Józef Flawiusz, Ant. 5,1.16.55; 13,1.5.24; 13,2.2.43; 13,5.4.145; 14,10.8.214.216; 17,9.6.246; 20,3.1.59), por. http://www.perseus. tufts.edu/ [dostęp stały].

${ }^{54} \mathrm{~W}$ rozpatrywanej księdze obecne są one jeszcze w 8,$31 ; 10,16 ; 12,14 ; 14,40 ; 15,17$. 
wieniu czasowników apostellō - histēmi a także 8,19 oraz $1 \mathrm{Krl}$ 19,7 i Joz 9,13 w wyrażeniu hodos pollē sfodra; odniesienie do dwóch odmiennych tekstów pozwala ocenić postępowanie dwóch adresatów w różnym świetle i pod różnym kątem, a także wydobyć te lub inne czynniki zawarte w motywacji lub celu jego działania; warunkiem prawidłowego odczytania tego typu aluzji jest absolutna niesprzeczność treściowa i teologiczna między nimi.

\section{A Theological Assessment of the Covenant between Judas Maccabeus and Rome: an Intertextual Analysis of 1 Macc 8:17-20}

\section{Summary}

What was the biblical interpretation of the Jews' conduct in the final stage of the history of Israel in the context of the Law of Moses right before the times of the New Testament? The proposed exegesis of 1 Macc 8:17-20, which describes the covenant between Judas Maccabeus and the Roman republic, strives to discover the theological evaluation of the behavior of the revolt's leader conducted by the author of the book. The intertextual method is particularly helpful in discovering the right understanding of the text. This method enables one to purposefully combine the expressions found in the consecutive verses with the same expressions found in the earlier biblical books. The theology that underlies these books will reveal the right sense of the studied passage of 1 Macc. It turns out that the theological evaluation is totally different than the political evaluation, the latter being solely taken into consideration in historical-literary analyses and commentaries. The biblical author has a restrained stance toward the political success of the Maccabees. He wants to reveal their conduct in the context of the Lord's Law, which strongly proves that the First Book of Maccabees should belong to the canon of the inspired texts.

\section{Keywords}

Old Testament, Septuagint, The First Book of the Maccabees, biblical exegesis, intertextuality

\section{Slowa kluczowe}

Stary Testament, Septuaginta, Pierwsza Księga Machabejska, egzegeza biblijna, intertekstualność 


\section{Skróty}

\section{Pisma starożytne (teksty oryginalne dostępne na: https://www.perseus.tufts.edu/)}

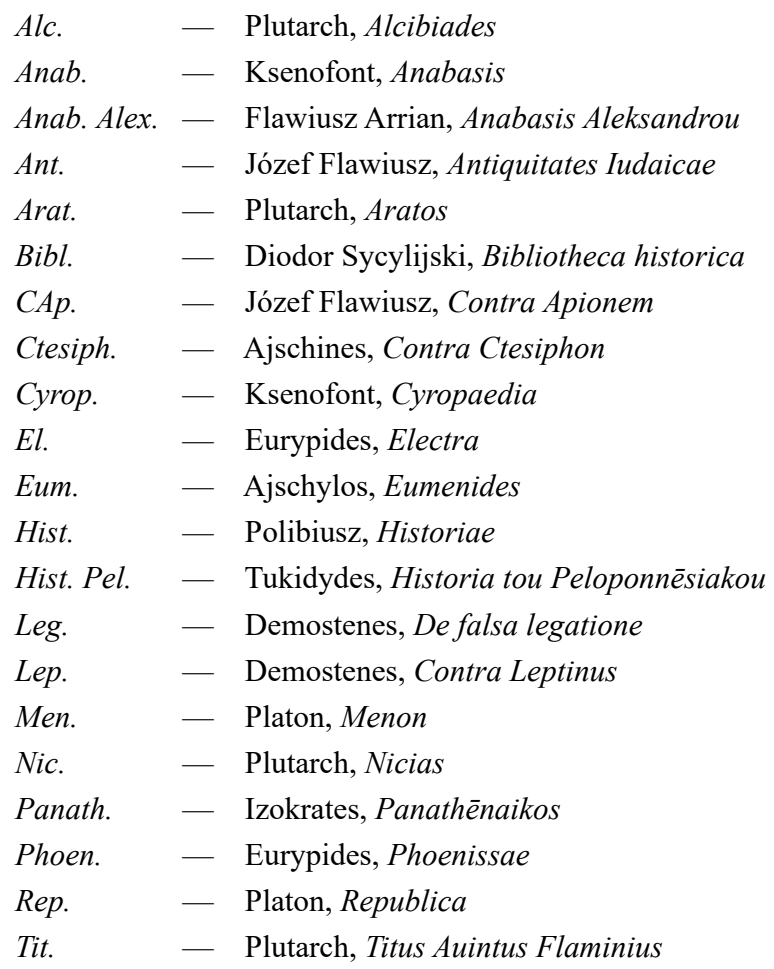

\section{Pozostałe}

$\begin{array}{lll}\text { AB } & - & \text { The Anchor Bible } \\ \text { BibAN } & - & \text { Biblical Annals } \\ \text { BN (NF) } & - & \text { Biblische Notizen (Neue Folge) } \\ \text { CBQ } & - & \text { Catholic Biblical Quarterly } \\ \text { FOTL } & - & \text { The Forms of the Old Testament Literature } \\ \text { NAC } & - & \text { The New American Commentary } \\ \text { NICOT } & - & \text { New International Commentary on the Old Testament } \\ \text { NKB.ST } & - & \text { Nowy Komentarz Biblijny. Stary Testament } \\ \text { PST } & - & \text { Poznańskie Studia Teologiczne } \\ \text { PŚST } & - & \text { Pismo Święte Starego Testamentu } \\ \text { SG } & - & \text { Studia Gnesnensia } \\ \text { WBC } & - & \text { Word Biblical Commentary }\end{array}$




\section{Bibliografia}

Bar-Kochva B., Judas Maccabaeus: The Jewish Struggle Against the Seleucids, Cambridge 2002.

Brzegowy T., Księga Izajasza, rozdziały 1-12, NKB.ST XXII/1, Częstochowa 2010.

Brzegowy T., Księga Izajasza, rozdziały 13-39, NKB.ST XXII/2, Częstochowa 2014.

Darsham G., The Original Language of 1 Maccabees: A Reexamination, BN (NF) 182 (2019), s. 91-110.

Fishbane M., Biblical Interpretation in Ancient Israel, Oxford 1988.

Garrett D., House P.R., Song of Songs, Lamentations, WBC 23B, Nashville 2004.

Gera D., Judaea and Mediterranean Politics: 219 to 161 B.C.E., Leiden-New York 1998.

Goldstein J., I Maccabees: A New Translation, with Introduction and Commentary, AB 41, Garden City 1976.

House P.R., 1-2 Kings: An Exegetical and Theological Exposition of Holy Scripture, NAC 8, Nashville 1995.

Keown G.L., Scalise P.J., Smithers T.G., Jeremiah 26-52, WBC 27, Dallas 1995.

Klein G.L., Zechariah: An Exegetical and Theological Exposition of Holy Scripture, NAC 21B, Nashville 2008.

Laskowski Ł., Druga Księga Machabejska, NKB.ST XIV/3, Częstochowa 2017.

Long B.O., 1 Kings with an Introduction to Historical Literature, FOTL IX, Grand Rapids 1984.

Łach J.B., Księgi 1-2 Królów. Wstęp - przekład z oryginatu - komentarz - ekskursy [w:] PŚST, t. IV, cz. 2, Poznań 2007.

Mandell S.R., Did the Maccabees Believe that They Had a Valid Treaty with Rome?, CBQ 53 (1991) 2, s. 202-220.

Nawrot J., Alliances between Israel and Other Nations in Light of the Pentateuch's Prohibitions in the Greek Bible, PST 35 (2020), pp. 29-48.

Nawrot J., Aluzje literackie w teologicznej ocenie działań arcykapłana Szymona w 1 Mch 14,5, BibAn 11 (2021) 1, pp. 5-23.

Nawrot J., Dlaczego oni zwyciężają? Teologiczna ocena judejskiej kampanii Antiocha V Eupatora w 1 Mch 6,47-54, SG 31 (2017), s. 85-103.

Nawrot J., Izrael wobec zakazu sprzymierzania się z poganami w wybranych tekstach Septuaginty: czesść I, PST 34 (2019), s. 7-28.

Nawrot J., Pierwsza Księga Machabejska. Rozdziały 1,1-6,16, NKB.ST XIV/I, Częstochowa 2016.

Nielsen K., Intertextuality and Biblical Scholarship, SJOT 4 (1990) 2, s. 89-95.

Oropeza B.J., Quotes, Allusions, and Echoes: Some Thoughts about What They Mean in Reference to Biblical Scripture, https:/www.academia.edu/38547991/Quotes_Allusions_and_Echoes_Some_Thoughts_about_What_They_Mean_in_Reference_to_ Scripture. 
Pucci J.M., The Full-Knowing Reader: Allusion and the Power of the Reader in the Western Literary Tradition, New Haven 1998.

Rocca S., The Late Roman Republic and Hasmonean Judaea, Athenaeum 102 (2014) 1, s. 47-78.

Seeman C., Rome and Judea in Transition: Hasmonean Relations with the Roman Republic and the Evolution of the High priesthood, New York 2013.

Smith G.V., Isaiah 1-39: An Exegetical and Theological Exposition of Holy Scripture, NAC 15A, Nashville 2007.

Stachowiak L., Księga Izajasza I 1-39. Wstęp - przekład z oryginału — komentarz [w:] PŚST, Poznań 1996.

Stern M., The Treaty between Judaea and Rome in 161 BCE, „Zion” 51 (1986), s. 3-28.

Stuart D., Hosea - Jonah, WBC 31, Waco 1987.

Thompson J.A., The Book of Jeremiah, NICOT, Grand Rapids 2007.

Vermeylen J., Du prophète Isaïe à l'apocalyptique. Isaïe I-XXXV, miroir d'un demimillénaire d'expérience religieuse en Israël, t. I, Paris 1977.

Wildberger H., Isaiah 1-12: A Continental Commentary, Minneapolis 1991.

Zollschan L., The Senate and the Jewish Embassy of 161 BCE [w:] The Path of Peace: Studies in Honor of Israel Friedman Ben-Shalom, ed. by D. Gera et al., Beersheva 2005, s. 1-37. 